\title{
Asian American History and the Perils of a Usable Past
}

\author{
Madeline Y. Hsu
}

One of the best-known photographs in Asian American history, Andrew Russell's "East and West Shaking Hands at Laying of Rail" (1869), famously includes no Asian Americans (Figure 1). Many have lamented the exclusion of Chinese laborers from these Union Pacific Railroad festivities, despite the fact that they comprised a majority of the railroad's labor force. ${ }^{1}$ Chinese laborers' "absence" from this iconic moment, showcasing the nation's technological and industrial accomplishments, became a rallying point for early generations of Asian American studies (AAS) scholars who heeded the battle cry to recover and to integrate the stories of Asians into the fabric of U.S. history. Chinese railroad workers have become stock figures in both historical and creative reconstructions of the Asian American past, commemorated for their key role in constructing the foundations of U.S. modernity, inscribed literally onto American landscapes, but just as much for having been erased from so many historical accounts. $^{2}$

This classic narrative about Russell's photograph has been qualified, albeit only slightly, by the observation that a Chinese man does appear in the photograph. He is recognizable only under close scrutiny. Gordon Chang, co-director of Stanford University's Chinese Railroad Workers in North America Project (CRRW Project), identifies him on the bottom row standing eighth from the left with his back facing the camera wearing a hat and patched coat. This recently noticed Chinese railroad worker underscores that although laborers like him feature in every Asian American history, they remain cardboard figures about whom very little detail is known. They have served as such effective political symbols for contesting the underappreciated role of Asian Americans in U.S. history that scholars have been largely content to let their appearances in historical accounts remain as transient as their roles had been working on the railroads. The time has come, and is perhaps overdue, for Asian American historians to move beyond advocacy projects and redouble efforts to research narratives that do not simply produce two-dimensional Asian American victims and heroes.

Doing so will not be easy. For example, as we near the 150th anniversary of the completion of the Transcontinental Railroad (and after some five decades of AAS), the CRRW Project finally aims to produce an ambitious social history of Chinese railroad workers, one that can represent their whole lives in three dimensions. Resources to do so are scant for this mobile, disposable workforce who left only bits and pieces of identifiable historical records. Perhaps

My thanks to Gordon Chang, Ed Dorn, and Sam Vong for commenting on a draft of this essay. To comply with strict word limits, I present a highly selective exploration of emerging lines of inquiry in Asian American history. Many excellent studies are unmentioned along with significant new approaches, such as critical refugee studies, international history, transnationalism, hemispheric migration, and intersectionality with gender and sexuality studies.

${ }^{1}$ See, for example, H. Mark Lai and Philip P. Choy, Outlines: History of the Chinese in America (1971; San Francisco, 1973), 59; Sucheng Chan, Asian Americans: An Interpretive History (Boston, 1991), 31. Erika Lee, The Making of Asian America: A History (New York, 2015), 73 describes their absence from photographs. Shelley Sang-Hee Lee, A New History of Asian America (New York, 2013), 64, observes that Chinese did attend the ceremonies and appear in photographs.

${ }^{2}$ William Cronon theorizes "second nature" in Nature's Metropolis: Chicago and the Great West (New York, 1991). Miners and agricultural workers also contributed to the remaking of North American landscapes.

(c) The Author(s) 2018. Published by Cambridge University Press 


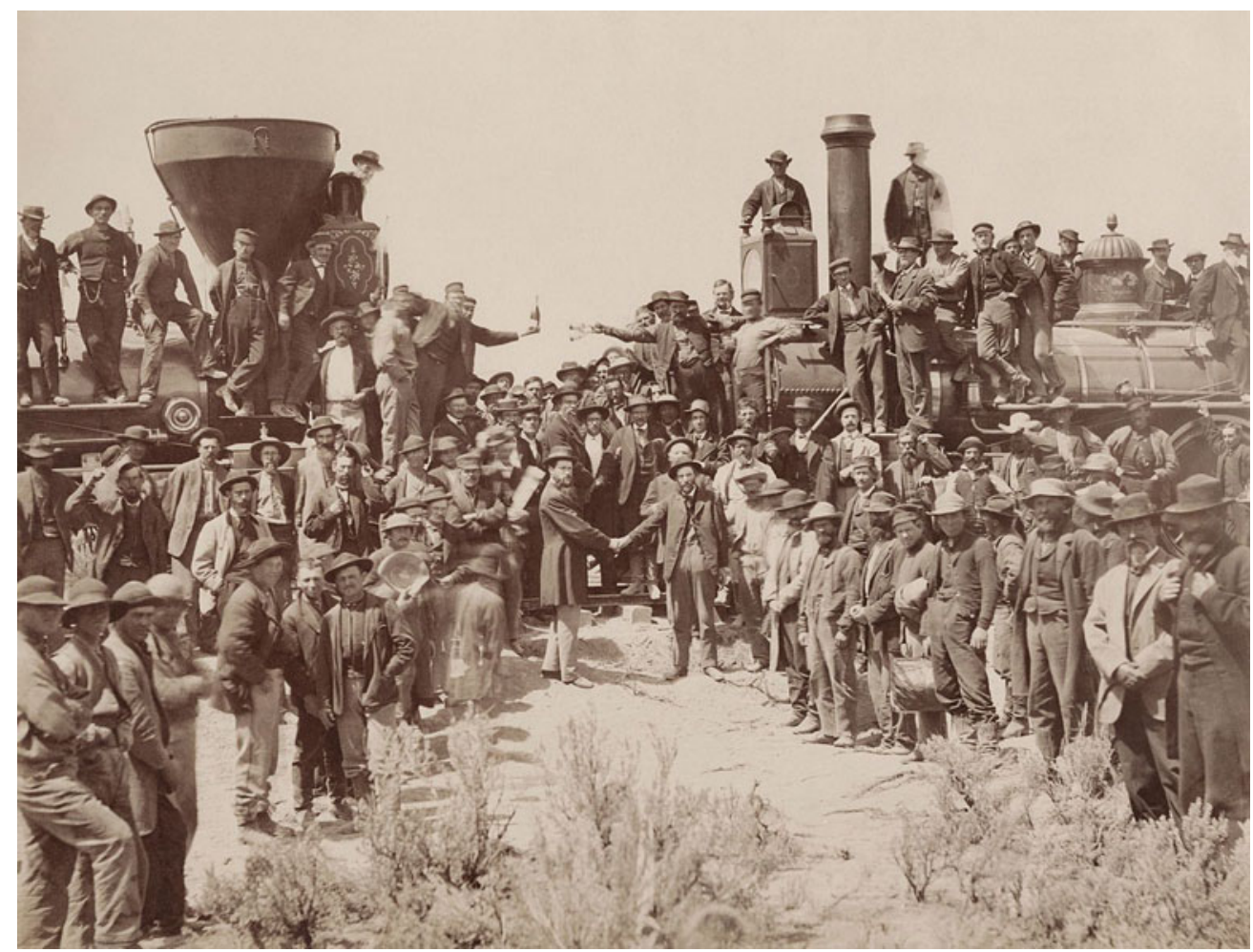

Figure 1. Can you find the Chinese man? "East and West Shaking Hands at the Laying of Last Rail Union Pacific Railroad" (1869) by Andrew Russell. Courtesy of Beinecke Library, Yale University.

so little has been written about Chinese railroad workers because so few traces remain. The most abundant records have proven to be glass, porcelain, metal fragments, and other Chinese artifacts from the campsites that are so pervasive throughout the west and southwest, which scores of archeologists have turned up in the course of their everyday work. ${ }^{3}$ Chinese gold miners, who are also iconic subjects, pose similar research challenges, as they begin to receive systematic attention as well. ${ }^{4}$

Political agendas have framed the research topics and interpretative frameworks chosen by AAS scholars since the 1970s. Fueled by the civil rights era's emphases on agency and demands for representation and inclusion into American society by excluded groups, Asian American historians sought to identify and protest systems of inequality while recovering, documenting, and celebrating the stories of Asian Americans. These projects significantly reinterpreted U.S. history and participated in the emerging fields of gender, social, immigration, legal, and labor histories, primarily by focusing on the dual trajectories of Asian Americans as victims and heroes. In a considerable but useful oversimplification, they were victims marginalized by structural and ideological discrimination who also became heroes by claiming America as their own and making lives in places from which they had been banned. ${ }^{5}$ Mae Ngai's multiple-award

\footnotetext{
${ }^{3}$ See the special issue of Historical Archaeology, "The Archaeology of Chinese Railroad Workers in North America," 49, no. 1 (March 2015).

${ }^{4}$ This is the focus of the comparative labor history project, "Yellow and Gold: The Chinese Mining Diaspora, 1848-1908," organized by Columbia University historian Mae Ngai.

${ }^{5}$ Vivek Bald's vivid Bengali Harlem and the Lost Histories of South Asian America (Cambridge, MA, 2012), for example, locates Bengali traders, former seamen, and workers in unexpected places, such as Detroit and New Orleans, during the 1910s and 1920s.
} 
winning first monograph, Impossible Subjects: Illegal Aliens and the Making of Modern America, exemplified both of these strains by exploring the legal, ideological, and institutional genealogies that disciplined, marginalized, and made illegal successive waves of Chinese, Filipinos, and Mexicans, some of whom nonetheless overcame discrimination in indelibly remaking a core American industry as agricultural laborers.

Ngai's second book, as nuanced and carefully researched as her first, has not received the same kinds of acclaim and attention, possibly because it departs from the heroes and victims framework. The Lucky Ones: One Family and the Extraordinary Invention of Chinese America recounts instead the less satisfying narrative of the morally ambiguous Tape family, who tried but were unable to Americanize. Missionary-raised Joseph and Mary Tape are best known for their 1885 court challenge to gain access to a white San Francisco public school on behalf of their daughter Mamie. Although the Tapes won in court and in principle, the California legislature quickly changed its laws to segregate the Tape children into a newly created "Oriental School" with other Chinese. Denied integration, the Tapes used their bilingual, bicultural advantages to operate as corrupt brokers who profited by enabling immigrant Chinese to negotiate the many legal restrictions placed on Asians in San Francisco. ${ }^{6}$ The Lucky Ones provides no triumphs of perseverance over discrimination, only the seamy realities of day-to-day choices made by those with limited legal options. Chinese would not become regular celebrants of immigrant rags-to-riches assimilation and success until the mid-twentieth century.

Brokers have inhabited politically unpalatable roles in immigrant communities, often by collaborating with powerful elites in ways that uphold existing hierarchies. But they have at the same time performed necessary services to other newcomers. They exemplify uncomfortable forms of complicity, but ones that have been as critical as radical politics in gaining visibility and greater rights for Asian Americans. For example, Charlotte Brooks's deeply researched, yet largely overlooked, Between Mao and McCarthy: Chinese American Politics in the Cold War Years explores the role of Chinese Americans who worked within mainline U.S. party politics-figures such as the postmaster of San Francisco, Lim P. Lee, who became the highest ranking Chinese American federal employee through his long record as an organizer for the Democratic Party. ${ }^{7}$ Some of the leaders who gained the greatest access for Asian Americans into political establishments were themselves outsiders who became skillful inside players.

Perhaps no individual Asian American exemplifies how the existence of such brokers challenges politically driven historical narratives more than Mike Masaoka, the self-proclaimed "Moses" for Japanese Americans during their darkest years of incarceration. ${ }^{8}$ Masaoka advised the U.S. government regarding terms for fellow U.S.-born Nisei citizens to be released from camp, producing processes that required Japanese Americans to display unequivocal loyalties to the very nation that had placed them behind barbed wire without due cause or due process. Masaoka had authored the creed of the Japanese American Citizen's League (JACL), which proclaimed beliefs in U.S. "institutions, ideals, and traditions" regardless of discriminations imposed and endured. In this vein, Masaoka urged Japanese Americans not to protest the curfew orders, evacuation, or incarceration and pressed Nisei men to volunteer for military service right out of camps and into the 442nd Regimental Combat Team as an opportunity for them to prove through blood sacrifice their commitments to the United States. Despite the great bitterness attending these conditions, the image of hyper-patriotic, civically compliant, and martially

\footnotetext{
${ }^{6}$ Mae M. Ngai, Impossible Subjects: Illegal Aliens and the Making of Modern America (Princeton, NJ, 2004) and The Lucky Ones: One Family and the Extraordinary Invention of Chinese America (Princeton, NJ, 2010). Lisa Rose Mar, Brokering Belonging: Chinese in Canada's Exclusion Era, 1885-1945 (Toronto, 2010) also explores brokers' critical yet ambiguous roles.

${ }^{7}$ Charlotte Brooks, Between Mao and McCarthy: Chinese Politics in the Cold War Years (Chicago, 2015).

${ }^{8}$ Mike Masaoka with Bill Hasokawa, They Call Me Moses Masaoka: An American Saga (New York, 1987). See Alice Yang Murray, Historical Memories of the Japanese American Internment and the Struggle for Redress (Stanford, CA, 2007) for the most extended discussion of Masaoka.
} 
heroic Japanese Americans laid powerful foundations for later political gains such as more equal immigration and citizenship rights, a Hollywood movie, Hawaiian statehood, electoral successes, and unquestionable inclusion as Americans, albeit in the form of the problematic model minority stereotype. ${ }^{9}$

Despite the overwhelming emphasis on World War II, incarceration, and the 442nd in Japanese American history, Masaoka is not a widely celebrated hero. Such accolades go instead to those who rejected his approach and challenged the curfew and incarceration orders, such as Fred Korematsu and Gordon Hirabayashi. Other celebrated Asian American heroes include those who confronted established authorities, such as the labor activists Larry Itliong and Philip Vera Cruz, or Black Panther-affiliated radicals such as Yuri Kochiyama and Grace Lee Boggs. Masaoka's marginalization in Asian American history runs so deep that supporters had to fight to include him in the National Japanese American Memorial to Patriotism During World War II erected in Washington DC in 2000. ${ }^{10}$

I recount these obscured pasts not because my colleagues in Asian American history and I have gotten our stories wrong, but because they are incomplete in ways that handicap our capacities to explain the persistence and remaking of racial differentiation and class inequalities. We no longer have to vindicate the importance of AAS projects, for our accomplishments have received acclaim and awards not just from the Association for Asian American Studies, but also from the American Historical Association, the Organization of American Historians, the American Studies Association, the Immigration and Ethnic History Society, the Society for Historians of American Foreign Relations, and the Western History Association. On top of such foundations, Asian American historians can now build more complex stories, exploring the nuances and ambiguities that surround historical actors and circumstances that may not fit neatly into our political projects but nonetheless illuminate how systems of power gain and maintain their hold. Broker figures, for example, reveal how particular hierarchies persist by coopting the aspirations and energies of the very persons and groups that they marginalize. What else is the model minority stereotype but a perniciously effective trope that takes the understandable ambitions of Asian immigrants and their children to succeed and gain inclusion and fashions them into a potent critique of other, so-called non-achieving minorities whose aspirations have been ignored and masked by long-standing structural barriers limiting access to education and employment?

Moving beyond our standard narratives of anti-Asian discrimination will open up new insights into the timing and substance of Asian exclusion, revealing how immigration restrictions have operated at the intersection of a wider array of ideological objectives that justified drastic expansions of federal authority and agencies in order to enforce their legally sanctioned discriminations. At their core, immigration controls reduce persons into designated categories of legal or illegal status with vastly different rights and protections. Hidetaka Hirota's Expelling the Poor: Atlantic Seaboard States and the Nineteenth-Century Origins of American Immigration Policy locates the origins of systematically enforced immigration restrictions, not with Chinese exclusion, but in the efforts of New York and Massachusetts to dispel poor Irish. Recent articles by Chang and Beth Lew-Williams emphasize the prolonged contestations and experimentation that characterized the early legislation and implementation of Chinese restriction, with Lew-Williams pushing the onset of exclusion to 1888. My monograph, The Good Immigrants: How the Yellow Peril Became the Model Minority, focuses on student exemptions to Chinese exclusion to explain how individual skills and employability have

\footnotetext{
${ }^{9}$ See Ellen D. Wu, The Color of Success: Asian Americans and the Origins of the Model Minority (Princeton, NJ, 2014).

${ }^{10}$ I thank Franklin Odo for describing this controversy to me. Masaoka appears as a supporting character in the Broadway musical "Allegiance" (2015-2016), which starred George Takei and a version of his family's World War II history.
} 
become the key rationales for immigration recruitment in ways that disguise racial discriminations. ${ }^{11}$ Indeed, although the goal of Asian exclusion was a general consensus by 1900 , the legal and administrative strategies used to do so varied depending on national origin and political circumstances. Asians did not come under unified immigration restrictions until Asian exclusion ended with the 1952 McCarran-Walter Act. ${ }^{12}$ Scrutinizing such nuances reveals how institutions for immigration restriction emerged contingently, as they experimented with administrative strategies and slowly accumulated authority in order to become more adept in disguising the inequalities they enacted and maintained. In this era of heightened conflict and controversy over how immigration, legal and otherwise, fits into the calculus of national well-being and security, digging into how these most openly discriminatory of government institutions have operated, and tracking the full implications of their power, are imperative projects.

Madeline Hsu is professor of history at UT Austin, and former director of the Center for Asian American Studies. She was born in Columbia, Missouri but grew up in Taiwan and Hong Kong between visits with her maternal grandparents at their store in Altheimer, Arkansas. Her monographs have received awards from the Association for Asian American Studies, SHAFR, IEHS, and the Asian Pacific American Librarians Association. Her third book is Asian American History: A Very Short Introduction (Oxford University Press, 2016). She is presently co-editing with María Cristina García and Maddalena Marinari an anthology titled "A Nation of Immigrants Explained: Immigration Policy, American Society, and the World, 1924-1965.”

\footnotetext{
${ }^{11}$ Hidetaka Hirota, Expelling the Poor: Atlantic Seaboard States and the Nineteenth-Century Origins of American Immigration Policy (New York, 2017); Gordon H. Chang, "China and the Pursuit of America's Destiny: Nineteenth-Century Imagining and Why Immigration Restriction Took So Long," Journal of Asian American Studies 15, no. 2 (June 2012): 145-69; Beth Lew-Williams, "Before Restriction Became Exclusion: America's Experiment in Diplomatic Immigration Control," Pacific Historical Review 83, no. 1 (February 2014): 24-56; Madeline Y. Hsu, The Good Immigrants: How the Yellow Peril Became the Model Minority (Princeton, NJ, 2015).

${ }^{12}$ Before 1952, immigration restrictions aimed for Asian exclusion premised on the ideological and legal ineligibility for U.S. citizenship of Asians first legislated in the 1790 Naturalization Act. Actual restrictions were more targeted, including the Chinese exclusion laws, the Gentlemen's Agreement for Japanese, and the 1917 Barred Zone Act. Even the general 1924 Immigration Act, which banned "aliens ineligible for citizenship" from immigrating, did not apply to Filipinos who were "nationals" from a U.S. territory. In 1934, the Tydings-McDuffie Act subjected Filipinos to restriction but provided a quota unavailable to other Asians. In 1943, Chinese gained citizenship rights and an immigration quota, as did Indians and Koreans in 1946. The 1952 McCarran-Walter Act legislated citizenship rights regardless of race and provided immigration quotas to all nations.
} 